\title{
Potential for seed production of non-traditional herbage species in New Zealand
}

\author{
J.G. HAMPTON', M.J. HILL', and M.P. ROLSTON ${ }^{2}$ \\ 'Seed Technology Centre, Massey University \\ ${ }^{2}$ DSIR Grasslands, Private Bag, Palmerston North
}

\begin{abstract}
The New Zealand herbage seed industry is looking to diversify and reduce its almost complete dependence on ryegrass and white clover. This review examines some opportunities and constraints to achieving this industry goal. In the near future, low input sustainable agriculture is likely to create a demand for seed of species such as alsike, Caucasian, zigzag and suckling clovers, crown vetch, velvet grass, white sweet clover, hairy canary clover, birdsfoot trefoil, perennial lupin, yarrow, tagasaste, wheat grass, oat grass, phalaris, paspalum, dogstail and sheep's burnet. There is also potential for export of herbage legumes such as annual medics, berseem clover, vetches, sainfoin, sulla, lotus and sweet clover, particularly to the Mediterranean region and Australia. The New Zealand seed industry has the strengths required to meet these challenges, and areas of lower fertility and free-draining irrigatable soils such as parts of Canterbury are likely to be highly suitable for -non-conventional herbage legume seed production. At present there are important constraints, including lack of seed supply and therefore little demand, very limited seed production information, lack of available financial resources, and competition from overseas producers. These problems are discussed. However, they can be overcome, and by 1995 New Zealand could expect commercial seed production of birdsfoot trefoil, sulla, perennial lupin, serradella, Caucasian and zigzag clovers, velvet grass, smooth and upland bromes, phalaris, paspalum, dogstail, dryland bent, yarrow and sheep's burnet. Brief seed production information for some of these species is appended.
\end{abstract}

Keywords herbage legumes and grasses, pasture herbs, forage shrubs, seed production potential, export, research, marketing

\section{Introduction}

New Zealand's herbage seed industry continues to be dominated by ryegrass and white clover. During $1987-89,68 \%$ of the $18475 \mathrm{t}$ of certified herbage seed machine dressed annually was ryegrass (Lolium spp), $25 \%$ was white clover (Trifolium repens) and only $7 \%$ was of other species (A.A. Johnson, pers. comm.). Of this total production, $65 \%$ was from just two cultivars, 'Grasslands Nui' perennial ryegrass and 'Grasslands Huia' white clover. Much of this production was to fill an opportune commodity market in North America (ryegrass) and traditional markets in Europe (white clover).

The dangers inherent in relying almost entirely on single cultivars and species are recognised, and the industry is slowly beginning to diversify, e.g. in 1988, $310 \mathrm{t}$ seed from 15 European white clover cultivars was produced in New Zealand for re-export. Also, certification entries for chicory (Cichorium intybus), cocksfoot (Dactylis glomerata), fescues (Festuca spp.), lotus (Lotus uliginosus) and phalaris (Phalaris aquatica) have increased significantly each year since 1987-88 (Anon. 1989), although in 1989 production was $>100 \mathrm{t}$ only for cocksfoot. In addition, in 1989, 3000 ha of US turf tall fescue cultivars were sown in New- Zealand for multiplication-and-re-export

Lancashire (1985) considered that the future challenge to the New Zealand seed industry was to enlarge and diversify both the internal and external demand for seed, and Rolston et al (1987) predicted that the herbage seed industry of the future would have a greater diversity of species, a greater emphasis on legumes, particularly for stress environments, and an increased export trade. The present and future place of species such as cocksfoot, tall fescue, prairie grass, browntop and red clover was discussed by Rolston et al. (1987). In this paper we examine further opportunities and constraints to achieving these industry goals.

\section{Opportunities}

Within New Zealand

In recent years there has been increasing interest in plant species adapted to drought-prone, low to moderate fertility soils that will grow with minimal fertiliser input. For example at low to moderate soil 
fertility sites in South Island hill country Scott et al (1985) suggested that species such as alsike, Caucasian, zigzag and suckling clovers (Trifolium hybridum, T. ambiguum, T. medium, T. dubium respectively), crown vetch (Coronilla varia), velvet grass (Holcus lanatus), white sweet clover (Melilotus $a l b a)$, birdsfoot trefoil(Lotus corniculatus), perennial lupin (Lupinus polyphyllus), yarrow (Achillea millefolium), tagasaste (Chamaecytisus palmensis), pubescent wheatgrass (Agropyron trichophorum), tall oat grass (Arrenatherum elatius) and sheep's burnet (Sanguisorba minor) all have particular features appropriate for these environments. Wills et al. (1989) also reported that hairy canary clover (Dorycnium hirsutum) had the ability to establish and grow in low fertility soils under cold dry conditions. Both phalaris (P. aquatica) and tall fescue (Festuca arundinacca) are suitable for use on drought-prone areas. Production data are being accumulated for a number of these species (e.g. Wills et al 1987; Daly \& Mason 1987; Fraser et al. 1988; Scott 1989; Wills et al. 1989). If pasture species are chosen firstly to meet the constraints of the environment, and secondly to utilise best the fertiliser rates able to be used, there will be a demand for supplies of seed of many of these 'non-conventional' species.

\section{For export}

Rolston et al. (1987) suggested that Australia and subtropical Asia were most likely to become important for New Zealand herbage seed exports, but there is also potential in much of the Mediterranean region. For example, Cocks (1988) reported that of 20 West Asian and North African countries, only two produce more than $10 \%$ of their existing requirements for herbage seed. The species required include forage legumes such as annual medics (Medicago spp), berseem clover (Trifolium alexandrinum), vetches (Vicia spp.), sainfoin (Onobrychis viciifolia), sweet clovers (Melilotus spp.) and sulla (Hedysarum coronarium) (Mansat 1988). Portugal imports seed of $\mathbf{T}$. alexandrinum, $\mathbf{T}$. incarnatum, Lotus spp. and Medicago spp. (Dordio 1988), and Iran imports T. alexandrinum (Rolston et al 1987). Demand for seed of Lotus corniculatus exceeds supply in many Mediterranean countries.

In Australia, seed supplies of annual medics are variable, while in the North American market, interest in ecologically balanced lawns could lead to demands for New Zealand yarrow (Achillea millefolium) and possibly strawberry clover (Trifolium fragiferum) (J.G.H. White, pers. comm.).

\section{Why New Zealand?}

The strengths of the New Zealand herbage seed industry as discussed by Rolston $\boldsymbol{e t}$ al. (1987) include climate, quality assurance, industry infrastructure, promotion, research and training. To those must be added farmer initiative and increasing expertise.
Research has provided the technology to produce consistently high yields of temperate herbage legumes through manipulating the limitations of the environment, particularly soil moisture and fertility (Rolston \& Clifford 1989). It is significant that white clover seed production research in Europe is now focusing on the Mediterranean region where seed yields are generally higher than those of northern Europe (Marshall \& Hides 1988) because of more reliable weather and the ability to manage water availability through irrigation. Many of the species suggested for New Zealand stress environments and required in southern Europe and northern African are Mediterranean in origin. Although the Canterbury climate does not match the typical Mediterranean climate (Lorenzetti 1988), the lowerfertility, free-draining irrigatable soils (Rolston \& Clifford 1989) are likely to be highly suitable for herbage legume seed production other than white clover.

\section{Constraints}

Species adoption

Daly \& Mason (1987) noted that "a constraint is the present lack of commercial seed supplies" (for $\mathbf{T}$. ambiguum and T. medium), and in 1990 seed of only 4/34 potential new species is freely available (Table 1). Certified seed production in 1989 was $127 \mathrm{t}$ for dogstail, $14 \mathrm{t}$ for velvet grass, $12 \mathrm{t}$ for serradella, $7 \mathrm{t}$ for phalaris (A.A. Johnson pers. comm.), and small quantities of upland and smooth brome and paspalum were also produced.

In many ways the quantity of seed available is a reflection of market demand. Use of many of these alternative species is at present limited to MAF and DSIR research trials, and the adoption of such species into commercial farming practice will require time, effective extension and good marketing. Until this happens and a demand for seed arises, it is likely that herbage seed producers and seed firms will move only cautiously and carefully. However, the economic reality of farming on lower fertility and/or drought prone land may well produce a more rapid adoption of new species than was the initial response for species such as 'Grasslands Roa' tall fescue and 'Grasslands Matua' prairie grass (Lancashire 1985).

\section{Seed production information}

The adoption rate of any new cultivar or species will also depend on the successful production of quality seed at an appropriate price. Of the 34 species (Table 1), some seed production information is available for sulla, birdsfoot trefoil, serradella, berseem and zigzag clover, smooth and upland brome, paspalum, phalaris, dogstail, velvet grass, sheep's burnet and tagasaste (see Appendix). For many of the other species, little published information is readily available, even internationally.

Seed production research for non-traditional species has begun at DSIR Grasslands Palmerston 
Table 1 Potential new herbage species for seed production in New Zealand

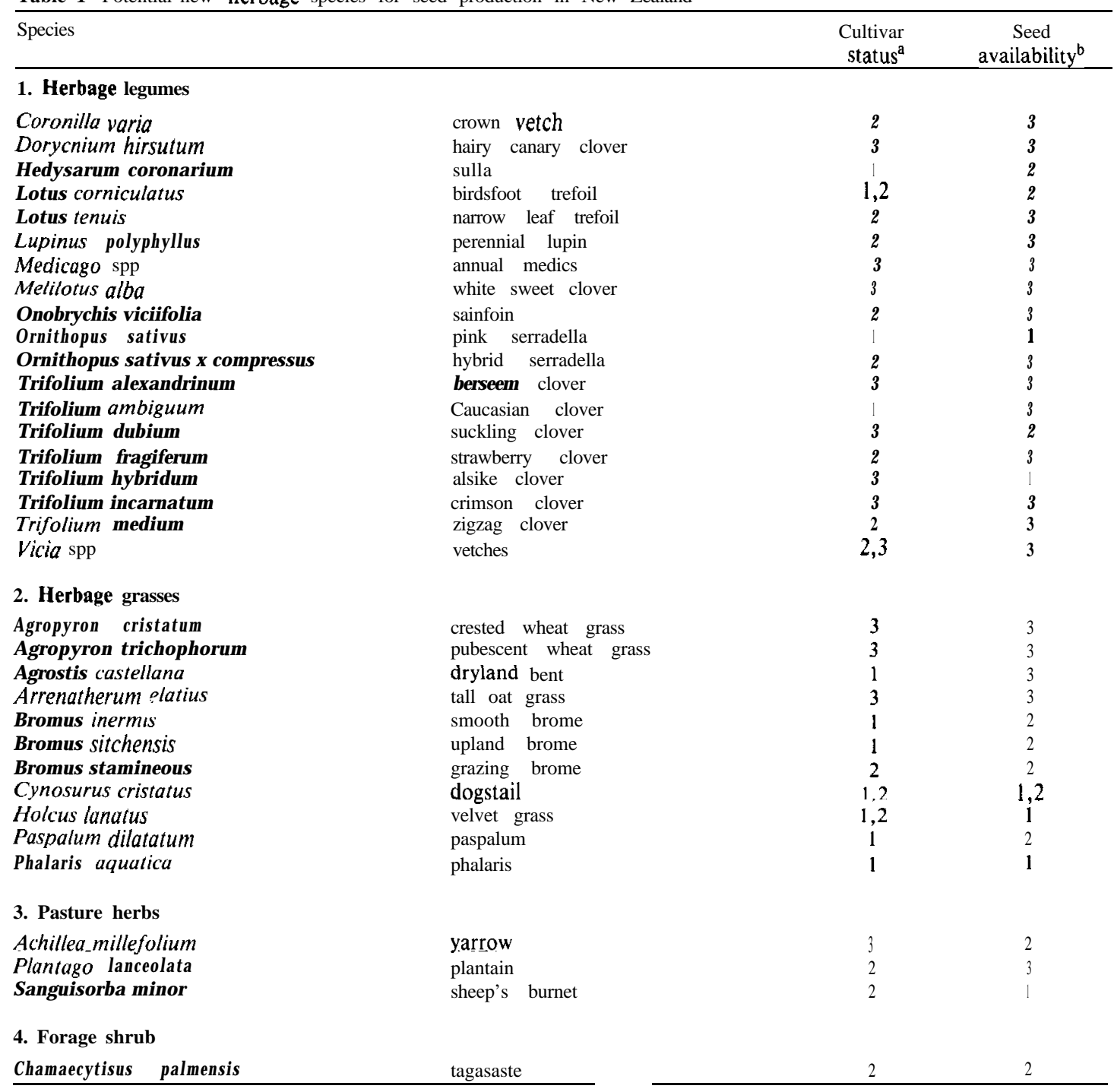

\section{a}

$$
\begin{aligned}
& \text { crown vetch } \\
& \text { hairy canary clover } \\
& \text { sulla } \\
& \text { birdsfoot trefoil } \\
& \text { narrow leaf trefoil } \\
& \text { perennial lupin } \\
& \text { annual medics } \\
& \text { white sweet clover } \\
& \text { sainfoin serradella } \\
& \text { pink serradella } \\
& \text { hybrid clover } \\
& \text { berseem clover } \\
& \text { Caucasian clover } \\
& \text { suckling clover } \\
& \text { strawberry clover } \\
& \text { alsike clover } \\
& \text { crimson clover } \\
& \text { zigzag clover } \\
& \text { vetches }
\end{aligned}
$$

crested wheat grass

dryland bent

tall oat grass

ooth brome

land brome

velvet grass

paspalum

Zealand cultivar status: 1 = named cultivar(s), $2=$ unnamed new selection shortly to be released as a cultivar, 3 = no known cultivars or possibly imported cultivars.

b Availability of seed: $\mathrm{I}=$ freely available, 2 = limited quantities available, 3 = only experimental quantities available.

North and Lincoln, and at both Massey and Lincoln Universities, and problems typical of all herbage legumes have been encountered, i.e. indeterminacy, protracted flowering periods, pollination problems, poor seed set, abortion, uneven ripening, pod shatter, harvesting difficulties and low harvest indices. For example, Cocks (1988) found that potential seed yield in Medicago rotata was around $2.4 \mathrm{t} / \mathrm{ha}$, but actual yield was often low because up to $90 \%$ of all flowers formed failed to develop mature pods; seed yields of perennial lupin should be from $0.5-2 \mathrm{t} / \mathrm{ha}$, but pod shatter is prevalent and seed is presently obtained by handpicking (Scott 1989); seed set in Trifolium medium is low because of poor pollination, and seed recovery is difficult because of the large amounts of vegetative dry matter produced (C. Mtolera, pers. comm.); only one in every 10 florets of Holcus lanatus supports a seed through to physiological maturity, and further losses then occur through seed shedding (Hampton unpub. data).

There are production constraints because of an information deficit, but compounding this are problems associated with funding for further research. At present, research is of necessity piecemeal and opportunistic, rather than working towards well planned long term goals. 


\section{Competition}

The world is not sitting back waiting for New Zealand to become suppliers of herbage seed. Although there are major problems, in for example many of the Mediterranean countries, in establishing local seed industries (Cocks 1988), they are being slowly overcome, and Mansat (1988) considered that a production capacity in the Mediterranean region may find markets in more northern latitudes particularly with the encouragement of generous EC research funding.

At present New Zealand does not have good market intelligence from potentially new importing countries, and information on seed supplies, trends for production and consumption, precise cultivar requirements and species preference is poor. Failure to obtain such information will result in lost opportunities. As Smith \& Mather (1985) noted, "we must listen to the market signals from our (present and potential) offshore consumers" and have our seed industry "move in positive fashions to the challenges in the future".

\section{Conclusion}

To increase and expand in internal and international markets, the New Zealand seed industry must continue to produce seed yields at relatively low costs per kilogram, and produce seed of the species and cultivars required by consumers. Can we do this for non-traditional species? Our assessment is as follows:

1. Commercial seed production operational by 1995 Hedysarum coronarium, Lotus corniculatus*, Lupinus polyphyllus, Ornithopus sativus, Agrostis castellana *, Bromus spp. Cynosurus cristatus, Holcus lanatus*, Phalaris aquatica, Paspalum dilatatum, Achillea millefolium *, Sanguisorba minor.

2. Commercial seed production ready to begin by 1995:

Coronilla varia, Lotus tenuis, Medicago spp*, O nobrychis viciifolia, Trifolium alexandrinum*, Trifolium hybridum, Trifolium incarnatum, Trifolium ambiguum, Trifolium medium, Agropyron spp., Chamaecystisus palmensis, Plantago lanceolata.

3. Little progress by 1995 :

Dorycnium hirsutum*, Melilotus alba* Trifolium dubium, Vicia spp., Árrenatherum elatius.

\section{ACKNOWLEDGEMENTS}

We thank the following colleagues for advice and seed production information: B.J. Wills and J.S. Sheppard, DSIR Alexandra and Christchurch; M.D. Hare, A.G. Foote, B.T. Bulloch, G.B. Douglas, DSIR Palmerston North; Li Qingfeng and Cunibert Mtolera, Seed Technology Centre, Massey University, J.G.H. White, Lincoln University.

* species with export potential.

\section{REFERENCES}

Anonymous 1989. Seed certification entries. Herbage Seed Growers' Subsection of Federated Farmers, Newsletter 411989

Cocks, P.S. 1988. The need for seed production of pasture and forage species. In Seed Production in and for Mediterranean Countries (eds A.J.G. van Gastel, J.D. Hopkins), ICARDA, Aleppo, Syria, 143-153.

Daly, G.T., Mason. C.R. 1987. Performance of Caucasian and zigzag clovers. Proceedings of the NZ Grassland Association 48:151-156.

Dordio, A.M. 1988. Production of forage and legume seed in Portugal. In Seed Production in and for Mediterranean Countries (eds A.J.G. van Gastel, J.D. Hopkins), ICARDA, Aleppo, Syria, 164-174.

Fraser, W.J.; Keoghan, J.M.; Heenan, R.P. 1988. Performance of Lotus corniculatus cultivars and lines in an altitudinal sequence on the east Otago plateau. Proceedings of the Agronomy Society of NZ 18: 53-57.

Lancashire, J.A. 1985. Some factors affecting the rate of adoption of new herbage cultivars. In Using Herbage Cultivars (eds R.E. Burgess, J.L. Brock), Grassland Research and Practice Series No. 3: 79-87. NZ Grassland Association.

Lorenzetti, F. 1988. Seed as a factor in the progress of Mediterranean agriculture. In Seed Production in and for Mediterranean Countries (eds A.J.G. van Gastel, J.D. Hopkins), ICARDA, Aleppo, Syria, 94-105.

Mansat, P. 1988. Seed production of forage legumes: needs, constraints and prospects. In Seed Production in and for Mediterranean Countries (eds A.J.G. van Gastel, J.D. Hopkins), ICARDA, Aleppo, Syria, 154-163.

Marshall, A.; Hides, D.H. 1988. Prospects of producing white clover seed in Mediterranean climates. In Seed Production in and for Mediterranean Countries (eds A.J.G. van Gastel, J.D. Hopkins), ICARDA, Aleppo, Syria, 175-182.

Rolston, M.P.; Clifford, P.T.P. 1989. Herbage seed: production and research - a review of 50 years. Proceedings of the NZ Grassland Assodation 50: 47-53.

Rolston, M.P.; Hampton, J.G.; Hare, M.D. 1987. Herbage seed: towards the year $\mathbf{2 0 0 0}$. Procedings of the Agronomy Sodity of NZ 17: 39-44.

Scott, D. 1989. Perennial or Russell lupin: a potential high country pasture legume. Proceedings of the NZ Grassand Assodiation 50: 203-206.

Scott, D.; Keoghan, J.M.; Cossens, G.G.; Maunsell, C.A.; Floate, M.J.S.; Wills, B.J.; Douglas, G. 1985. Limitatons to pasture production and choice of species.In Using Herbage Cultivars (eds R.E. Burgess, J.L. Brock), Grassland Reserch and Practice Series No. 3: 9-15. NZ Grassland Association.

Smith, R.G.; Mather, R.D.J. 1985. Marketing herbage seeds. In, Using Herbage Cultivars (eds R.E. Burgess J.L. Brock), Grassland Reserch and Practice Series No. 3: 93-95. NZ Grassland Association.

Wills, B. J.; Sheppard, J.S.; Begg, J.S.C. 1987. Evaluation of alternative dryland pasture plants and browse shrubs for soil conservation in drought-prone Otago grasslands. Proceedings of the NZ Grassland Assodation 48: 115-1 18.

Wills, B.J.; Begg, J.S.C.; Foote, A.G. 1989. Dorycnium species - two new legumes with potential for dryland pasture rejuvenation and resource conservation in New Zealand. Proceedings of the NZ Grassland Assodiation 50: $169-174$ 


\section{Appendix: Sked production notes}

\section{Sullla (Hedysarum coronarium)}

$\square$ responds best to mild winters and warm summers; warm dry summers essential for optimal seed production.

$\square$ grows well on any well-drained soil with $\mathrm{pH}$ of 6-8. Does not like heavy or sandy soils.

(1) sow late summer-early autumn, using pre-sowing weed control (trifluralin); seed-bed should be deeply worked, compacted and fine surfaced. Correct $\mathrm{P}$ and $\mathrm{K}$ deficiencies if below moderate levels.

$\square$ seed benefits from dehulling and scarification; inoculate with NZP5410 rhizobia.

$\square$ drill or broadcast at $5-10 \mathrm{~kg} / \mathrm{ha}$ (dehulled) or $15-20 \mathrm{~kg} / \mathrm{ha}$ (hulled); harrow and roll after broadcasting.

$\square$ weed control post emergence necessary (metribuzin, dinoseb, propyzamide).

$\square$ do not cut or graze autumn sown crops before seed harvest; established stands can be grazed during winter and early spring.

$\square$ peak flowering occurs late spring-early summer; honey bees are good pollinators.

$\square$ harvest 7-8 weeks after peak flowering when $50-60 \%$ of hulls have turned brown; mow with sickle bar or rotary disc mower, leave in windrow for 3-5 days before harvesting.

口 yield potential over $1000 \mathrm{~kg} / \mathrm{ha}$, but typical yields range from $150-500 \mathrm{~kg} / \mathrm{ha}$ of unhulled seed.

2. Birdsfoot trefoil (Lotus corniculatus)

$\square \quad$ will persist under low fertility, but for seed production moderate soil fertility and $\mathbf{p H} 6-7$ required

$\square$ early autumn sow at $3-5 \mathrm{~kg} / \mathrm{ha}$ depending on hard seed content (often around 30\%); slow to establish; inoculate seed prior to sowing, $30 \mathrm{~cm}$ row spacing.

$\square$ trifluralin presowing, and 2,4-DB in early winter for weed control; interrow cultivate in early spring before new crop growth begins; in established crops .use paraquat plus atrazine $(0.5+1.0 \mathrm{~kg}$ a.i./ha) for weed control.

$\square$ an insecticide (e.g. Mavrik Aquaflow) may be required to control sucking insects before and after flowering.

$\square$ do not graze in the establishment year; in subsequent crops close in late September.

$\square$ a long flowering period leads to uneven ripening and losses through pod shatter; plant growth regulators may help to overcome this problem.

[] cut the crop 35-38 days after peak flowering (70-80\% of pods light brown) and thresh as soon as the fleshy stems have dried sufficiently to feed through the combine without 'wrapping'.

$\square \quad$ seed yields of $300 \mathrm{~kg} / \mathrm{ha}$ are considered good, but yields of over $600 \mathrm{~kg} / \mathrm{ha}$ have been obtained; seed can be harvested for up to six seasons.

\section{Berseem clover (Trifolium alexandrinum)}

$\square$ requires well drained, fertile, loamy soils; light, sandy and acidic soils are unsuitable

$\square$ autumn sow at $\mathbf{2 0 - 2 5} \mathrm{kg} / \mathrm{ha}$; inoculation with appropriate Rhizobium bacteria essential.

$\square$ grazing or cutting available in early spring, but must cease by mid October to allow at least 10 weeks for reproductive growth and seed maturation.

[] swath harvest by cutting when $65-70 \%$ of pods are brown; field dry for $3-4$ days before combining.

4. Zigzag clover (Trifolium medium)

$\square$ perennial which spreads readily by rhizomes; resembles red clover.

$\square$ sow at $2 \mathrm{~kg} / \mathrm{ha}$ in $30-60 \mathrm{~cm}$ rows.

[ in established-crops, white clover can be controlled with métribuzin.

$\square$ cross pollinated, primarily by long tongue bumble bees, as corolla tube too long for pollination by honey bees.

$\square$ seed yields low because of genentic factors (highly polyploid), clover seed chalcid damage, long flowering period, large vegetative mass and 'burial' of seed heads within the canopy.,

\section{Smooth brome (Bromus inermis)}

$\square$ a rhizomatous species adapted to dry environments and cold winters.

$[$ requires free draining soils of moderate fertility.

[] sow in spring at $5 \mathrm{~kg} / \mathrm{ha}$ in IS-20 $\mathrm{cm}$ rows.

$\square$ graze once established and IO-15 cm tall; apply $40 \mathrm{~kg} \mathrm{~N} / \mathrm{ha}$ in autumn and continue to graze until winter growth stops; do not graze below $3 \mathrm{~cm}$.

[] apply $40 \mathrm{~kg} \mathrm{~N} / \mathrm{ha}$ in late September.

[] seeds brown when mature and very light so that airflow within the combine must be reduced to a minimum

[ after harvest bale or burn off straw; hard graze in early autumn, apply $40 \mathrm{~kg} \mathrm{~N} / \mathrm{ha}$ in autumn and continue grazing until closing.

[ ] seed yields of $200 \mathrm{~kg} / \mathrm{ha}$ have been obtained.

6. Upland brome (Bromus silchensis)

$\square$ resembles prairie grass $(B$. wildenowii) but less winter growth and lower fertility requirements, ph 5.5-6.5.

[ a autumn sow de-awned, fungicide-treated seed at $5-10 \mathrm{~kg} / \mathrm{ha}$ in $15-30 \mathrm{~cm}$ rows.

$\mathrm{Cl}$ lax graze down to $5 \mathrm{~cm}$ during winter, close later September.

L] apply 80-100 kg N/ha at closing and cycocel (CCC) at I.0 litre/ha in early October to reduce lodging.

[] cut at $45-48 \%$ seed moisture content and thresh at $14 \%$ SMC; further dry to $10-12 \%$ SMC.

L] provided head smut does not occur, a second year crop can be taken.

[] yields range from $1000-1500 \mathrm{~kg} / \mathrm{ha}$. 
7. Phalaris (Phalaris aquatica)

$\square$ requires deep but free draining soils, $\mathrm{pH}$ 6-7, moderately fertile.

[ sow early autumn at $3-5 \mathrm{~kg} / \mathrm{ha}$ in $30 \mathrm{~cm}$ rows.

$\mathrm{Cl}$ early weed control (Poa annua and other weeds) essential for good tiller development.

- lax graze down to $5 \mathrm{~cm}$ during winter; close late September and apply 80-100 kg N/ha

$\square$ a fungicide spray between ear emergence and anthesis may be necessary; crops grow $200 \mathrm{~cm}$ tall!

$\square$ harvest when most seeds are fawn-brown; olive or white seeds are immature; direct head or mow and thresh after 4-5 days' drying.

$\square$ burn or bale straw, graze regrowth but watch for phalaris staggers; autumn fertilise with NPK, and late autumn spray with atrazine, simazine or diuron.

$\square$ seed yields of $600 \mathrm{~kg} / \mathrm{ha}$ possible, but more commonly $300400 \mathrm{~kg} / \mathrm{ha}$.

8. Dogstail (Cynosurus crisfafus)

$\mathrm{Cl}$ requires well drained averge fertility soils with $\mathrm{pH}$ 5.8-6.

$\square \quad$ usually late spring sown (November/December) by broadcasting at $18 \mathrm{~kg} / \mathrm{ha}$, often with a turnip cover crop $(0.25 \mathrm{~kg} / \mathrm{ha})$.

$\mathrm{Cl}$ pre-emergence weed control with MCPA or MCPB

$\square$ graze lightly in late summer/autumn, and again in following spring, but close in mid October; autumn nitrogen (20-30 kg/ha) should be applied to encourage tillering before winter.

$\square$ harvest around 5 weeks after flowering by windrowing when seed is "biscuit brown" combine 5-7 days later; alternative direct head at 35\% SMC and dry to $12 \%$ SMC.

$\square$ burn or bale straw and provided stand is weed free, a second year crop can be harvested.

yields of $1000 \mathrm{~kg} / \mathrm{ha}$ have been recorded, but the average is from $350-500 \mathrm{~kg} / \mathrm{ha}$.

9. Velvet grass (Holcus lanatus)

$\square$ grows on a wide range of soil types, prefers $\mathrm{pH} 5-7.5$, but will tolerate lower $\mathrm{pH}$.

$\square$ autumn sow at $1-3 \mathrm{~kg} / \mathrm{ha}$ in $30-45 \mathrm{~cm}$ rows; correct $\mathrm{P}$ and $\mathrm{K}$ deficiencies if necessary, but autumn $\mathrm{N}$ not required

$\mathrm{Cl}$ winter graze if required, but close in early September; apply $50-90 \mathrm{~kg} \mathrm{~N} / \mathrm{ha}$ at closing.

a very prone to seed shedding and wind can cause large losses; cut at 40\% SMC and swath dry to $14 \%$ SMC before combining; alternatively direct combine at 35\% SMC and rethresh 2-3 days later to remove all seeds; dry to $14 \%$ SMC.

$\square$ yields range from $250-800 \mathrm{~kg} / \mathrm{ha}$; most losses are associated with harvest.

10. Sheep's burnet (Sanguisorba minor spp. muricafa)

$\square$ likes light, well drained fertile soils, pH 5-6; moderately warm dry climate, water in spring; shelter from wind during harvest will help prevent seed shatter.

$\square$ autumn sow in frost free areas, or spring sow if risk of frost heavy, preceded by effective autumn-winter cultivation to eradicate potential weed species (couch, white clover, yarrow, sorrel); incorporate EPTC into soil prior to sowing.

$\square$ requires firm, well-tilled, weed free seed-bed; sow at $4-8 \mathrm{~kg} / \mathrm{ha}$ at depth at $5-10 \mathrm{~mm}$; emergence may take $3-4$ weeks.

$\square \quad$ apply $\mathrm{N}(50-80 \mathrm{~kg} \mathrm{~N} / \mathrm{ha}$ ) in early spring at closing.

$\square$ use simazine or chlorozuron post emergence in new stands; MCPA + paraquat will give good weed control in mature crops.

$\square$ do not graze in first seed production season; grazing of mature crops should leave $10-40 \mathrm{~mm}$ herbage to ensure vigorous regrowth.

$\square \quad$ an extended flowering period and uneven seed set make correct harvest timing difficult; susceptible to bird damage; harvest when $70-80 \%$ of the seed heads become brown and feel firm; direct head or pick up cut swath; yields range from $250-500 \mathrm{~kg} / \mathrm{ha}$.

\section{Tagasaste (Chamaecytisus palmensis)}

$\square$ prefers freely drained soils with $\mathrm{pH}$ 5.5-7.5; avoid water logged soils.

$\square$ grows well in most cool temperate environments, but frost sensitive as small plant

$\square$ autumn sow in mild winter areas, but spring sow in cooler regions; as presently hand harvested, sow $<1$ ha; sow at $10-20 \mathrm{seeds} / \mathrm{m}$ of row at depth of $2-\mathrm{S} \mathrm{cm}$; seed requires scarification, and inoculation (use Lotus uliginosus inoculant); seed bed should be fine and firm; rolling after sowing aids establishment; seedlings can also be transplanted.

$\square$ metribuzin, pendimethalin and simazine are successful pre-emergence herbicides, and slug and snail bait (e.g. methiocarb) may be required.

$\square$ row spacing depends on farming system and other use (e.g. shelter, coppice, forage - minimum $3 \mathrm{~m}$ ).

$\square \quad 25 \mathrm{~g}$ superphosphate/m row beneficial, otherwise only correct soil deficiencies.

$\square$ rabbit protection (netting or electric wires) essential.

[ no grazing or cutting until after first seed harvest.

$\square \quad$ flowering usually starts 2 years after sowing, appearing in winter and peaking in later winter-early spring; often fewer than half the flowers set seed; insect pollination not required.

[] pick pods when brown-black and dry slowly; thresh by rolling tractor over them or belt threshing; single plant may yield $300 \mathrm{~g}$ clean seed.

$\square$ after harvest trim plants to $2 \mathrm{~m}$ for ease of harvesting in following year 